\title{
Rice phyllosphere bacteria producing antifungal compounds as biological control agents of blast disease
}

\author{
SRI MARTINA WIRASWATI ${ }^{1}$, ABDJAD ASIH NAWANGSIH ${ }^{2}$, IMAN RUSMANA ${ }^{1}$, ARIS TRI WAHYUDI ${ }^{1, \bullet}$ \\ ${ }^{1}$ Department of Biology, Faculty of Mathematics and Natural Sciences, Institut Pertanian Bogor. Jl. Agatis, Dramaga, Bogor 16680, West Java, \\ Indonesia. Tel./fax.: +62-251-8622833. "email: aristri2011@gmail.com \\ ${ }^{2}$ Department of Plant Protection, Faculty of Agriculture, Institut Pertanian Bogor. Jl. Agatis, Dramaga, Bogor 16680, West Java, Indonesia
}

Manuscript received: 8 January 2020. Revision accepted: 2 March 2020.

\begin{abstract}
Wiraswati SM, Nawangsih AA, Rusmana I, Wahyudi AT. 2020. Rice phyllosphere bacteria producing antifungal compounds as biological control agents of blast disease. Biodiversitas 21: 1273-1278. In vitro analysis of rice phyllosphere bacteria can be developed as biocontrol agents of blast disease using their antifungal activity. To prove the efficacy of bacterial isolates in reducing the severity of blast disease, a greenhouse experiment was conducted. Furthermore, antifungal compounds produced by potential bacterial isolate were also identified using Thin Layer Chromatography (TLC) and Liquid Chromatography-Mass Spectrometry/ Mass Spectrometry (LC-MS/MS) analysis. The application of seven rice phyllosphere bacterial isolates significantly reduced the severity of blast disease in rice (var: Ciherang). Surprisingly, the isolate STGG 14 is the most effective with $70.83 \%$ of blast disease reduction. Isolate STGG 14 has been identified as Bacillus subtilis subsp. subtilis which is known as various bioactive compounds producer. It was confirmed through identification of antifungal compounds produced by isolate STGG 14. The bioautography test shows that crude bioactive compounds from isolate STGG 14 could inhibit $P$. oryzae race 173 . On the further analysis using LC-MS/MS, four bioactive compounds isolated from isolate STGG 14 were identified as moracin C, psoralen, 4,6-dimethyl-3 (4'-hydroxyphenyl) coumarin and xanthotoxin. All identified compounds except moracin $\mathrm{C}$, belong to the coumarin group. According to the previous studies, among all compounds, psoralen and xanthotoxin displayed antifungal activity against several fungal pathogens.
\end{abstract}

Keywords: Bacillus, bioactive compounds, bioautography, Pyricularia oryzae, TLC

\section{INTRODUCTION}

The phyllosphere is defined as aerial or above-ground parts of plant including stem, leaves, flowers, buds, and fruits, whereas surface area of leaves constitute phylloplane. This niche is considered as hostile environment due to large fluctuations of physical and nutritional conditions (Batool et al. 2016). Nevertheless, phyllosphere environment is inhabited by a large and diverse microorganism including bacteria, fungi, yeast and archaea which have commensal, pathogenic and mutualistic interactions with the host plant. Leaves are the most dominant aerial part which occupied by bacteria as the most abundant resident (Rastogi et al. 2013). Bacterial density in the leaf surface reaching as high as $10^{5}-10^{7}$ cells per gram of plant material (Yadav et al. 2010) and majority of them are commensal (Ali et al. 2012). Phyllosphere bacteria are capable to protect host plants from pathogens through indirect mechanisms such as production of antimicrobial compounds and competition of resources. Antimicrobial compounds will be secreted by phyllosphere bacteria in order to create a competitive environment for inhibiting the growth of plant pathogens (Chaudhary et al. 2017). Bacteria producing antimicrobial compounds especially antifungal properties have been studied and applied to manage plant pathogens. Bacillus, Pseudomonas, and Pantoea are examples of bacteria that potentially produce antifungal compounds against fungal pathogens such as Pythium, Fusarium oxysporum,
Rhizoctonia solani (Junaid et al. 2013) and Pyricularia oryzae (Sha et al. 2016). Generally, Bacillus species have been known as lipopeptides compounds producer with fungal cell wall degradation activity (Tserkovniak et al. 2009) such as fengycin and iturin. Both lipopeptides groups are able to inhibit the growth of filamentous fungi through destruction of sterol, phospholipid and oleic acid on the fungal cell membrane (Gond et al. 2015).

Rice fungal pathogen from Ascomycete group, Magnaporthe oryzae (anamorph: P. oryzae) is the most devastating pathogen in rice plant cultivation. This pathogen belongs to the top 10 fungal diseases that endanger universal food security (Dean et al. 2012). Pyricularia oryzae is the causing agent of blast disease in rice that attacks leaves, culms and panicles of rice plants as well as decreases photosynthesis effectivity and grain yield (Ribot et al. 2008). Among all parts of rice plants that are infected by $P$. oryzae, neck blast is the most destructive form of blast disease (Zhang et al. 2014). This disease spread in more than 85 countries and has caused great yield loss. At least $30 \%$ of the rice harvest is lost due to blast disease infection annually. This amount is equal with rice necessary to feed more than 60 million people for 1 year (Sha et al. 2016). To deal with it, the use of bacteria to reduce crop diseases particularly blast disease seems to be the most suitable way to replace synthetic fungicide (Junaid et al. 2013). The application of bacteria producing antifungal compounds can be effective if they are able to colonize the host plant properly. Likewise, in managing 
blast disease, the biocontrol agents should be able to survive on the stems and leaves of rice plants. Therefore, the use of phyllosphere bacteria as biocontrol agents is predicted to be a reliable method for managing foliar diseases like rice blast.

In the previous study, we successfully isolated seven rice phyllosphere bacteria with antifungal activity against $P$. oryzae race 173 in vitro analysis. Among the seven bacterial isolates, five isolates were Bacillus species (isolates STGG 3, STGG 7, STGG 8 and STGG 14), one isolate was Enterobacter species (isolate STGV 8) and the other isolate was Brachybacterium species (isolate SKBG 78). These isolates have been proved to have the ability to produce bioactive compounds (Wiraswati et al. 2019). Furthermore, to confirm the efficacy of these isolates in reducing the severity of blast disease in rice plants, a greenhouse experiment was conducted in this study. Effect of crude bioactive compounds toward morphological alteration of $P$. oryzae race 173 was observed under SEM. Besides, thin layer chromatography and LC-MS/MS analysis were also carried out to identify the antifungal compounds produced by phyllosphere bacteria.

\section{MATERIALS AND METHODS}

\section{Procedures}

\section{Bacterial strains}

The seven bacterial isolates used in this research were obtained from the previous study by Wiraswati et al. (2019). The bacterial strains were isolated from rice phyllosphere environment which is taken from Cikembar sub-district, Sukabumi and Situgede sub-district, Bogor, West Java, Indonesia. The bacterial isolates were previously identified as Bacillus sp. STGG 3 (GenBank Accession No: MN240450), B. subtilis STGG 7, B. amyloliquefaciens STGG 8, B. subtilis subsp. subtilis STGG 14 (GenBank Accession No: MN240448), $B$. subtilis SKBV 1 (GenBank Accession No: MN240449), Enterobacter cloacae STGV 8 (GenBank Accession No: MN240451) and Brachybacterium paraconglomeratum SKBG 78 (GenBank Accession No: MN240452).

\section{Greenhouse experiment: efficacy of bacteria to control blast disease}

Plant material and biocontrol agents. This experiment used rice variety of Ciherang as plant material which susceptible to rice blast disease. The rice seeds were sown on soil for 14 days and then 5 rice plants were transferred to pots containing the mixture of paddy field soil and organic fertilizer $( \pm 300 \mathrm{~g})$. For bacterial application, seven rice phyllosphere bacteria (STGG 3, STGG 7, STGG 8, STGG 14, SKBV 1, STGV 8 and SKBG 78) were inoculated on $200 \mathrm{~mL}$ Luria Bertani (LB) broth medium $(1 \% \mathrm{NaCl}, 1 \%$ Tryptone, $0.5 \%$ Yeast extract, $2 \%$ agar in 1 $\mathrm{L}$ distilled water) for 4 days or until reached $\pm 10^{8} \mathrm{cfu} \mathrm{mL}^{-1}$ of bacterial density. Afterward, these bacterial cultures were applied twice, i.e 7 and 14 days after planting (dap) by spraying a total of $20 \mathrm{~mL}$ of bacterial culture per pot. This experiment was run with complete randomized design using 10 treatments which consisted of 7 bacterial isolates, commercial fungicide with isoprotiolan as active ingredient (Fujiwan 400EC), pathogen (P. oryzae race 173) and sterile distilled water. Each treatment was replicated 3 times and each replication consisted of 5 rice plants. The pathogen treatment without bacteria (PT) was used as positive control of disease, while sterile distilled water treatment without pathogen and bacteria (WT) was used as negative control.

Conidial production. In this study, we used $P$. oryzae race 173 from Indonesian Center for Rice Research (ICRR) collection. The pathogen mycelial block agar was transferred to Petri dishes containing oatmeal agar medium (3\% oatmeal, $2 \%$ agar in $1 \mathrm{~L}$ of distilled water) and incubated for 10 days at room temperature $\left( \pm 25^{\circ} \mathrm{C}\right)$. The fungal cultured was then aseptically scrapped with small brush and exposed with neon lamps for 2 days. Afterward, the conidial were harvested by adding sterilized water containing $0.1 \%$ tween 80 and conidial concentration was quantified using haemacytometer and adjusted to final concentration $2 \times 10^{5}$ conidial $\mathrm{mL}^{-1}$. The conidial inoculum was applied at 21 dap by spraying it in to the rice plants. Immediately after pathogen inoculation, the rice plants were transferred to a moist room which maintained at $25 \pm$ $2{ }^{\circ} \mathrm{C}$ of temperature with relative humidity of $90 \pm 5 \%$. The rice plants were then submitted to an initial $48 \mathrm{~h}$ dark period for penetration of conidia and blast disease development (Harsonowati et al. 2017). Afterward, the rice plants were transferred to a greenhouse and kept for a long experimental period. The temperature and humidity inside the greenhouse were maintained at $25 \pm 2{ }^{\circ} \mathrm{C}$ (day) to $20 \pm$ $2{ }^{\circ} \mathrm{C}$ (night) and $90 \pm 5 \%$, respectively. The non-inoculated pathogens of rice plants were sprayed with sterile distilled water as a negative control, while the positive control of blast disease was sprayed by pathogen inoculum and sterile distilled water.

\section{Extraction of crude bioactive compounds from isolate STGG 14}

Isolate STGG 14 was grown in $1 \mathrm{~L} \mathrm{LB}$ broth medium and incubated at $150 \mathrm{rpm}$ for 4 days. Crude bioactive compounds were obtained by using ethyl acetate as solvent (Islam et al. 2012). The bacterial culture was mixed with ethyl acetate with a ratio of 1: $1(\mathrm{v}: \mathrm{v})$ and vigorously shaken for 1 hour. Afterward, the organic layer was collected and evaporated by using vacum evaporator at $40^{\circ} \mathrm{C}$ of temperature. The resulted crude extract was stored at $5^{\circ} \mathrm{C}$ for further analysis.

\section{Effect of crude extract toward Pyricularia oryzae race 173}

The effect of crude extract from isolate STGG 14 toward the alteration of fungal mycelium was determined using Scanning Electron Microscope (SEM) JSM-5310LV (Jeol Ltd., Japan). Antifungal activity assay of crude extract was conducted using agar diffusion method. The Potato Dextrose Agar (PDA) medium (3\% PDA (Himedia); $1 \mathrm{~L}$ distilled water) which contained $500 \mathrm{ppm}$ of crude extract was solidified in Petri dishes and then $5 \mathrm{~mm}$ of fungal mycelium block agar was grown above the PDA medium. In addition, fungal pathogen which grown in the 
PDA medium without crude extract was used as a negative control. After 10 days of incubation, the fungal mycelium was prepared for SEM observation. Fungal mycelium was excised and cleaned by soaking in cacodylate buffer for 2 hours and agitated in ultrasonic cleaner for $5 \mathrm{~min}$. Afterward, sample prefixation was done by soaking in $2.5 \%$ glutaraldehyde for 2 days and fixation sample by soaking in $2 \%$ tannic acid for several days. Furthermore, sample was cleaned with cacodylate buffer for $5 \mathrm{~min} ; 4$ times. Dehydration step was conducted by soaking the sample in a graded alcohol concentration $(50 \%, 70 \%, 85 \%$, $95 \%$, and $100 \%$ ) for $20 \mathrm{~min}$ for each concentration. The last step was draining the sample by soaking it in tert butanol for $2 \times 10 \mathrm{~min}$, freezing it in the freezer and transferring it to the freeze-drying instrument. Before observation step, the dry sample was coated with aurum (Au) using ion coater.

\section{Thin layer chromatography analysis}

The crude extract from isolate STGG 14 was separated using TLC plates (TLC silica gels $60 \mathrm{~F}_{254}, 20 \times 20 \mathrm{~cm}$, layer thickness $0.25 \mathrm{~mm}$, Merck, Darmstadt, Germany). The crude extract was dissolved using methanol to final concentration of $200 \mathrm{mg} \mathrm{mL}^{-1}$. Afterward, the dissolved extract was injected into TLC plates using CAMAG Linomat 5 and developed using eluent system: acetone: chloroform $(\mathrm{v} / \mathrm{v}=1 / 1)$ as optimum eluent. Eluent residue was removed by incubating the TLC plates at room temperature for 15 minutes. The separated compounds were visualized under UV light with $254 \mathrm{~nm}$ and $366 \mathrm{~nm}$ wavelength using CAMAG TLC Visualizer 2.

\section{TLC direct bioautography analysis}

Ten microliters of methanol dissolved extract $(200 \mathrm{mg}$ $\mathrm{mL}^{-1}$ ) were loaded to TLC plates (TLC silica gels $60 \mathrm{~F}_{254}$, $2 \times 10 \mathrm{~cm}$, layer thickness $0.25 \mathrm{~mm}$, Merck, Darmstadt, Germany) and separated using eluent system: acetone: chloroform ( $\mathrm{v}: \mathrm{v}=1: 1)$ in the TLC chamber. The TLCdirect bioautography test was conducted using agar diffusion method. Mycelia of $P$. oryzae race 173 was harvested from 7 days old of fungal culture $\left(10^{6} \mathrm{cfu} \mathrm{mL}^{-1}\right)$ which previously grew on PDB medium and mixed with 15 $\mathrm{mL}$ of PDA medium $\left(48^{\circ} \mathrm{C}\right)$. Furthermore, the developed TLC plates were placed aseptically in the Petri dishes and covered with PDA broth medium that contained fungal mycelia. After 10 days of incubation, antifungal activity of crude extract was observed. The active fraction with antifungal activity was characterized by clear zone around the developed TLC plate.

\section{Isolation of antifungal compounds from TLC plate}

A total $600 \mu \mathrm{L}$ of crude extract $\left(200 \mathrm{mg} \mathrm{mL}^{-1}\right.$ in methanol) was injected into TLC plates (TLC silica gels $60 \mathrm{G} \mathrm{F}_{254}$ Glass Plates $20 \times 20 \mathrm{~cm}$, layer thickness $0.25 \mathrm{~mm}$, Merck, Darmstadt, Germany) and developed in acetone: chloroform $(\mathrm{v} / \mathrm{v}=1 / 1)$ as mobile phase eluent. Afterward, the developed TLC plate was visualized under UV light and the active fraction with antifungal activity was marked. The active fraction with high antifungal activity was scrapped out from the developed TLC plates and mixed with methanol as solvent. The organic layer was then separated by centrifugation in $5,000 \times \mathrm{g}$ and evaporated at $40^{\circ} \mathrm{C}$ of temperature for 2 days.

\section{Identification of antifungal compounds}

The isolated antifungal compounds were identified using LC-MS/MS analysis with Acquity UPLC ${ }^{\circledR} \mathrm{H}-\mathrm{Class}$ System dan Xevo G2-S QTof (Waters, USA). This analyzer was equipped with capillary column Acquity $\mathrm{UPLC}^{\circledR} \mathrm{HSS} \mathrm{C} 18(1.8 \mu \mathrm{m} 2.1 \times 100 \mathrm{~mm})$. The LC column and room temperature were programmed at $50^{\circ} \mathrm{C}$ and $25^{\circ} \mathrm{C}$. The mixture of water $+5 \mathrm{mM}$ ammonium formic and acetonitrile $+0.05 \%$ formic acid was used as mobile phase with sample flow rate of $0.2 \mathrm{ml} / \mathrm{min}$. Meanwhile, the desolvation temperature of MS analysis was programmed at $350^{\circ} \mathrm{C}$ with desolvation gas flow rate and collision energy of 793 L/hour and 4 volts, respectively. Furthermore, the chromatogram and mass spectra were analyzed and interpreted using MassLynx V.4.1 program. The $\mathrm{m} / \mathrm{z}$ peaks of antifungal compounds were compared with the mass spectrum database in Chemspider (www.chemspider.com) and Massbank website (www.massbank.jp).

\section{Data analysis}

\section{Blast disease assessment and statistical analysis}

The severity of blast symptoms on the experimental rice plant was observed every 3 days until 21 days after inoculation (dai) of pathogen using a standard evaluation system for rice blast with 6 ratings: 0 , no lesions; 1 , not more than five lesions, and no longer than $10 \mathrm{~mm} ; 3,6-10$ lesions, longer than $10 \mathrm{~mm}$; 5, 11-25 lesions, covering between 10 and $25 \%$ of total leaf area; 7 , more than 26 lesions, covering between 26 and $50 \%$ of total leaf area; 9 , lesion area greater than $50 \%$ of total leaf area (Yang et al. 2007). At the end of observation, blast disease severity was calculated using the following formula:

$$
\text { Disease seventy }=\frac{2_{1}^{z a}(n x v)}{\mathrm{NxZ}} \times 100 \%
$$

Where: $n$ is the number of leaves infected by blast disease, $v$ is value score of blast disease, $\mathrm{N}$ is the total of leaves observed, and $\mathrm{Z}$ is the value of the highest score blast disease. Afterward, means of blast disease severity and disease reduction were calculated and statistically analyzed using a one-way analysis of variance (ANOVA) and Tukey's honestly significant difference test at 5\% probability level using SPSS version 20.0 (SPSS, IBM, Armonk, NY, USA).

\section{RESULTS AND DISCUSSION}

\section{Antifungal activity of phyllosphere bacteria in greenhouse experiment}

The seven bacterial isolates are significantly capable in reducing rice blast disease in greenhouse compared to control of pathogen (PT). The least blast symptoms were discovered in rice plants treated with isolate STGG 14, 
compared to rice plants treated with isolate STGV 8 (Figure 1). Furthermore, isolate STGG 14 also significantly reduced blast disease at $70,83 \%$ reduction with relative inhibition that was higher than fungicide treatment (Figure 2). Thus, isolate STGG 14 can be developed as biocontrol agents of blast disease dan selected for further analysis in this study.

\section{Morphological alteration of pathogen-induced by crude extract}

Crude bioactive compounds were extracted from isolate STGG 14 with ethyl acetate as solvent. From $7 \mathrm{~L}$ of bacterial culture, we obtained $0.944 \mathrm{~g}$ of crude bioactive compounds extract. The effect of crude extract toward $P$. oryzae was displayed by cracked hyphae (Figure 3.B), curly shaped and smaller size of hyphae (Figure 3.C) under scanning electron microscope observation. Meanwhile, the hyphal morphology in the control treatment grew normally with compact shaped (Figure 3.A). Furthermore, the growth of $P$. oryzae in the PDA medium with crude extract was also slower than the control experiment.

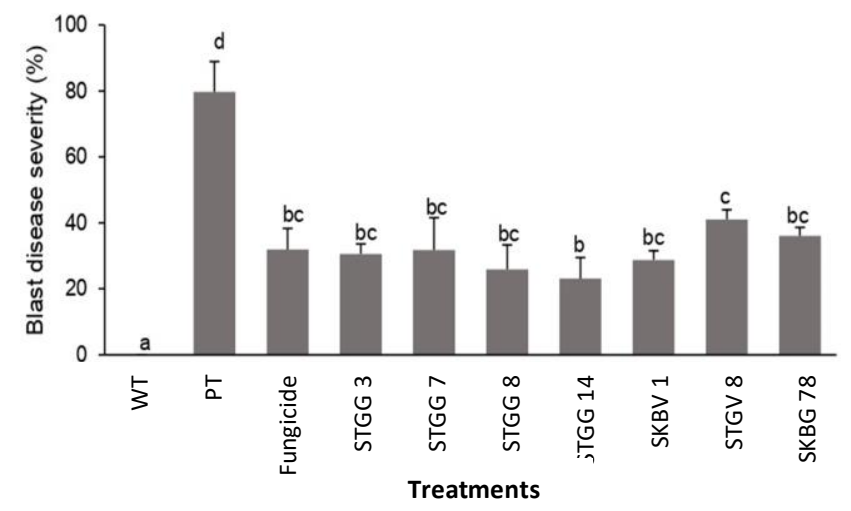

Figure 1. Blast disease severity on rice variety Ciherang treated with rice phyllosphere bacteria at 21 days after pathogen inoculation compared to control pathogen. Bars shared the same letter is not significantly different according to Tukey's honestly significant difference test $(p \leq 0.05)$. WT is water treatment without pathogen and bacteria, PT is pathogen treatment without bacteria.
TLC analysis of antifungal compounds from isolate STGG 14

Optimation of mobile phase was trialed using 9 solvent during TLC analysis and resulted in the mixture of acetone/chloroform $(\mathrm{v} / \mathrm{v}=1 / 1)$ as the most optimum eluent for crude extract separation from isolate STGG 14. TLC fractionation of crude extract resulted in 10 fractions on the TLC plate (Figure 4A). The bioautography test showed that fraction $8(\mathrm{Rf}=0.83)$ and $9(\mathrm{Rf}=0.86)$ displayed antifungal activity with no mycelium growth around the spot (Figure 4.B).

\section{Isolated antifungal compounds}

Two active fractions corresponding to fungal inhibition were successfully purified from TLC plate using methanol as solvent. We obtained $0.074 \mathrm{~g}$ and $0.033 \mathrm{~g}$ of extract from fractions 8 and 9. Each isolated compound from spot 8 and 9 was further dissolved in methanol for LC-MS/MS analysis.

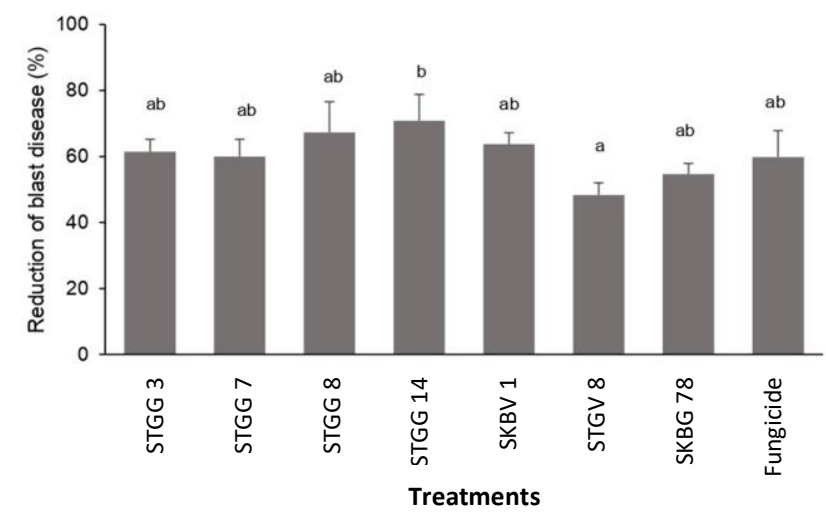

Figure 2. Reduction of blast disease in rice plant treated with rice phyllosphere bacteria and fungicide at 21 days after pathogen inoculation in greenhouse. Bars shared the same letter is not significantly different according to Tukey's honestly significant difference test $(p \leq 0.05)$.

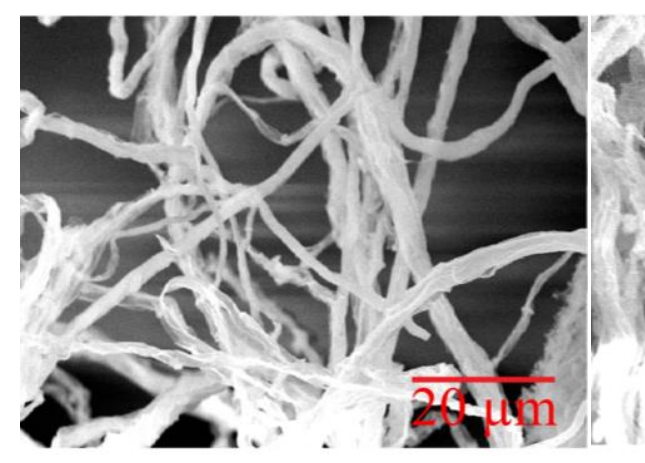

A

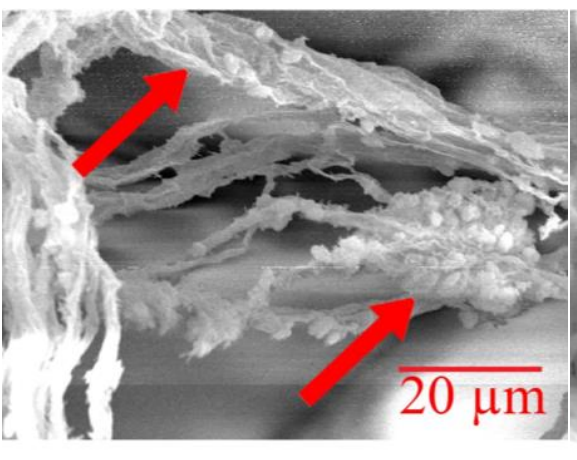

B

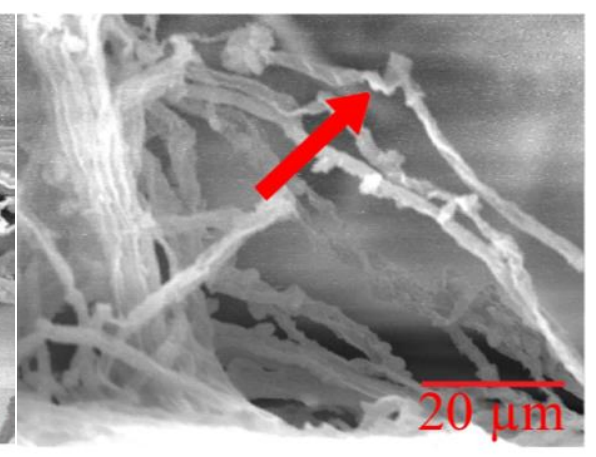

C

Figure 3. Morphology of $P$. oryzae race 173 under scanning electron microscope observation with 2000 times of magnification: A. Normal hyphae of $P$. oryzae on the PDA medium; B. cracked hyphae; C. Hyphae with curly shaped; b and c were grown in PDA medium with crude bioactive compounds from isolate STGG 14. Red arrows showed hyphal damage due to crude extract treatment. 
Table 1. Identified bioactive compounds produced by isolate STGG 14 and their bioactivities

\begin{tabular}{lccll}
\hline \multicolumn{1}{c}{ Identified compounds } & Formula & Mass & \multicolumn{1}{c}{ Bioactivity } & \multicolumn{1}{c}{ References } \\
\hline Psoralen & $\mathrm{C}_{11} \mathrm{H}_{6} \mathrm{O}_{3}$ & 186 & Antifungal & Yu et al. (2017) \\
Xanthotoxin (8-methoxypsoralen) & $\mathrm{C}_{12} \mathrm{H}_{8} \mathrm{O}_{4}$ & 216 & Antifungal, antibacterial & Al-Barwani and Eltayeb (2004) \\
Moracin C & $\mathrm{C}_{19} \mathrm{H}_{18} \mathrm{O}_{4}$ & 310 & Antiinflammatory & Yao et al. (2016) \\
4,6-dimethyl-3 (4'-hydroxyphenyl) coumarin & $\mathrm{C}_{17} \mathrm{H}_{14} \mathrm{O}_{3}$ & 266 & Antibacterial & Asif (2015) \\
\hline
\end{tabular}

\section{Antifungal compounds from isolate STGG 14}

According to LC-MS/MS analysis, fraction 8 consisted of four dominant peaks, while fraction 9 consisted of two dominant peaks. The dominant peak 1 (Retention time= $8.65 \mathrm{~min})$ and $2(\mathrm{Rt}=9,47 \mathrm{~min})$ from fraction 8 as well as dominant peak $1(\mathrm{Rt}=8,63 \mathrm{~min})$ and $2(\mathrm{Rt}=9,49 \mathrm{~min})$ from fraction 9 were identified as psoralen and xanthotoxin. Meanwhile dominant peak $3(\mathrm{Rt}=10,08)$ and $4(\mathrm{Rt}=10,86)$ from fraction 8 were successfully identified as moracin $\mathrm{C}$ dan 4,6-dimethyl-3 (4'-hydroxyphenyl) coumarin. These identified compounds belong to furanocoumarin group except moracin $\mathrm{C}$. The psoralen and xanthotoxin were reported to have antifungal activity against several fungal pathogens on the previous study (Table 1).

\section{Discussion}

The seven rice phyllosphere bacteria from West Java, Indonesia previously proved to have antifungal activity against $P$. oryzae in vitro analysis and potentially developed as biocontrol agents of blast disease. Before releasing the potential bacteria to the field, we have to prove that their antifungal activities against $P$. oryzae are also effective in rice plants. Therefore, this present study aims to reveal the efficacy of these bacterial isolates in reducing blast disease severity in greenhouse. The in planta analysis of bacterial isolates shows that the isolate has an ability to decrease severity of blast disease in rice variety Ciherang. All phyllosphere bacterial treatments significantly reduce blast disease severity compared to pathogen treatment (PT) with various relative inhibition percentages. Isolates STGG 3, STGG 4, STGG 7, STGG 8 and SKBV 1 which are identified as Bacillus spp. show higher antifungal activity than isolates SKBG 78 and STGV 8 which are identified as Brachybacterium paraconglomeratum and Enterobacter cloacae. The ability of Bacillus species to inhabit the various environments will facilitate the bacteria to survive and colonize the aerial part of rice plant. Beside, Bacillus species have a role in plant growth stimulation as studied by Sunera et al. (2020) that isolated $B$. cereus from rhizosphere of tomatoes plant. In addition, Bacillus spp. also produce a number of bioactive compounds that have important roles in decreasing rice blast severity. Meanwhile, B. paraconglomeratum and E. cloacae which are known as plants growth promoter are predicted to have lower ability in colonizing the rice leaves, so that they display low antifungal activity.

Among seven rice phyllosphere bacteria, isolate STGG 14 shows the highest activity in reducing blast disease with $70.83 \%$ of relative inhibition (disease severity: $23.11 \%$ ). Interestingly, isolate STGG 14 also shows higher blast disease reduction than commercial fungicide, Fujiwan 400 EC (Figure 2) which is commonly used by farmers in Indonesia. Isolate STGG 14 which is identified as $B$. subtilis subsp. subtilis is commonly used as biocontrol agents of various plant pathogens (Zhang et al. 2012) such as Fusarium oxysporum, Colletotrichum capsici, Rhizoctonia solani, etc. On the other hand, isolate STGV 8 which is identified as E. cloacae displayed the lowest relative inhibition to blast disease, ie. $48.35 \%$ (disease severity: $41.07 \%$ ). This finding indicated that B. subtilis subsp. subtilis has a better ability than E. cloacae (isolate STGV 8) in reducing rice blast disease severity in greenhouse.

In this study, B. subtilis subsp. subtilis STGG 14 displayed constant antifungal activity both in vitro and in planta analysis. The efficacy of $B$. subtilis subsp. subtilis STGG 14 in reducing blast disease is caused by its ability to produce antifungal compounds. Our previous study successfully amplified Adenilation (A) domain as well as Ketosynthase (KS) domain of cluster gene NRPS and PKS from B. subtilis subsp. subtilis STGG 14 (Wiraswati et al. 2019). A domain and KS domain have a role in antimicrobial compounds synthesis which belong to nonribosomal peptide and polyketide groups such as lipopeptide, macrolide, and polyene compounds. Several previous studies mentioned that $B$. subtilis subsp. subtilis can produce antifungal compounds like iturin, fengycin, surfactin (Dimkić et al. 2017) and bacilysocin (Tamehiro et al. 2002).

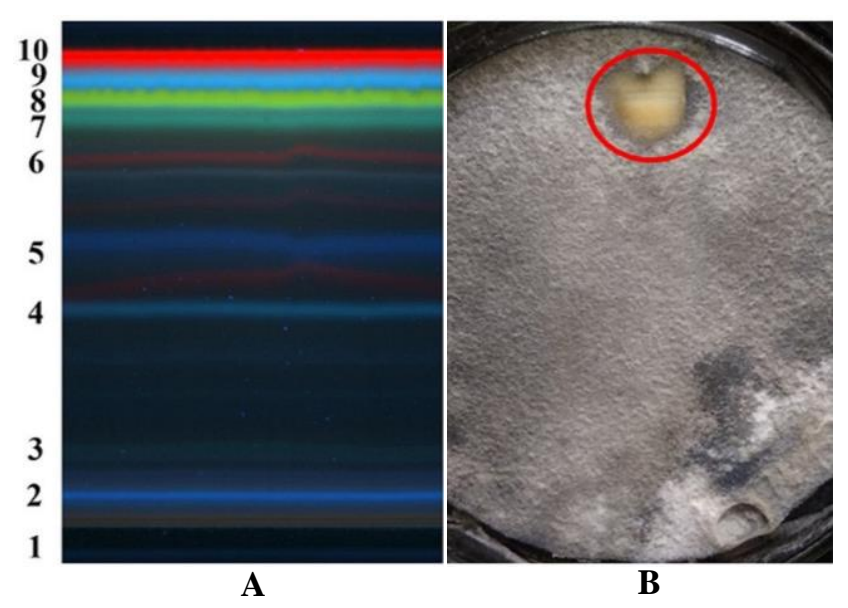

Figure 4. Purification of antifungal compounds from isolate STGG 14: A. TLC profile of crude bioactive compounds resulted in 10 fractions; B. TLC directed bioautography test observed after 10 days of incubation 
In addition, Islam et al. (2012) and Luo et al. (2015) reported that B. subtilis subsp. subtilis $\mathrm{C} 9$ and $B$. subtilis 916 produced acetyl butanediol, bacilomycin $\mathrm{L}$ and surfactin that suppressed the growth of $R$. solani. Bacillus subtilis strain Y-IVI was able to produce iturin A and fengycin which have a role in suppressing $F$. oxysporum in Muskmelon (Zhao et al. 2016). Meanwhile, Hanene et al. (2012) also reported that fengycin produced by B. subtilis SR146 could inhibit the growth of $F$. oxysporum, $F$. melonis, $F$. equiseti, and $F$. solani.

As mentioned before, Bacillus species including $B$. subtilis are very beneficial for agricultural purposes due to its ability to produce bioactive compounds. To prove it, we extracted crude bioactive compounds from isolate STGG 14 which were previously known to have antifungal activity against $P$. oryzae race 173 in vitro analysis (Wiraswati et al. 2019). The results of this study can be seen as evidence that isolates STGG 14 could produce antifungal compounds, which contribute to the rice blast disease control in greenhouse. To determine the fungicidal effect of extracted bioactive compounds, morphological observation was conducted toward $P$. oryzae race 173 According to Scanning Electron Microscope (SEM) observation, the crude antifungal compounds triggered abnormal fungal mycelium of $P$. oryzae that characterized by cracked hyphae (Figure 3B), curly shaped and smaller size hyphae (Figure 3C) than control hyphae. Meanwhile, $P$. oryzae without antifungal compounds treatment has a compact shaped of mycelium and grew normally (Figure 3A). As reported by Semangun (2006), antifungal compounds from plants and microbial extracts displayed several inhibition mechanisms toward fungal pathogens such as cell membrane permeability alteration and cell wall degradation. Suriani et al. (2015) declared that the alteration of hyphae and spores size of $P$. oryzae caused by lysis of mycelium cell phenomenon. Additionally, Liao et al. (2016) also informed that the application of fengycin from $B$. amyloliquifaciens BPD1 toward $P$. oryzae resulted in swollen and cracked mycelium. The inhibition of fungal growth by antifungal compounds from isolate STGG 14 informs us that the crude extract displays fungistatic mode of action, because the extracted antifungal compounds only inhibit the growth of $P$. oryzae race 173 without killing the pathogen.

The identification of antifungal properties from isolate STGG 14 is important to understand the specific mechanism of the bacteria in controlling blast disease. Crude extract was separated using thin-layer chromatography and then antifungal compounds were detected by TLC-direct bioautography. Eluent optimation was resulted in a combination of chloroform and acetone $(\mathrm{v} / \mathrm{v}=1 / 1)$ as the most effective eluent to separate the crude extract. We obtained 10 fractions from TLC separation and among them, 2 fractions displayed antifungal activity against $P$. oryzae through bioautography test. Antifungal activity was characterised by clear zone formation around the spot $8(\mathrm{Rf}=0.83)$ and $9(\mathrm{Rf}=0.86)$ (Figure $4 \mathrm{~b})$. According to LC-MS/MS analysis, fraction 8 consists of 4 bioactive compounds i.e moracin C, psoralen, 4,6dimethyl-3 (4'-hydroxyphenyl) coumarin and xanthotoxin (8-methoxypsoralen), while fraction 9 consists of 2 bioactive compounds i.e psoralen and xanthotoxin (8methoxypsoralen) (Table 1). These identified bioactive compounds have resulted from crude extract which isolated extracellularly from isolate STGG 14 .

Interestingly, all identified compounds (except moracin C) belong to the furanocoumarins group which is generally responsible for antimicrobial activities (Aslam et al. 2010). In addition, among all identified compounds, only psoralen and xanthotoxin which displayed antifungal activity against some fungal pathogens according to several previous studies. Furanocoumarins are linear coumarins with benzopyrone compounds that belong to flavonoid groups that usually presented in several natural products and obtained by plant extraction or microbial synthesis. More than 1300 coumarins have been identified as secondary metabolites from plants, bacteria, and fungi such as Aspergillus sp., Ganoderma lucidum, Penicillium sp., Streptomyces strain and Bacillus strain (Costa et al. 2016). Coumarin derivatives such as xanthotoxin and bergapten demonstrated antifungal activity against Alternaria sp., Bipolaris sp., and Fusarium sp. (Al-Barwani and El-tayeb 2004). Meanwhile, psoralen, linear furanocoumarins, also displayed antifungal activity against $R$. solani, Botrytis cinerea, Alternaria solani and Giberela zeae in vitro analysis ( $\mathrm{Yu}$ et al. 2017). Despite their potential as antifungal compounds, some coumarins are also regarded as phytoalexins which are synthesized by plant tissues in response to the pathogens infection, thus triggering the plant resistance (Yang et al. 2017). Psoralen and xanthotoxin compounds which successfully identified from B. subtilis subsp. subtilis STGG 14 has not been reported before. Therefore, the research finding that shows $B$. subtilis subsp. subtilis as bacteria having ability to produce antifungal compounds from coumarins group except lipopeptides compounds become new information that never been reported before.

To conclude, isolate B. subtilis subsp. subtilis STGG 14 shows the highest activity in reducing blast disease severity in rice plant variety Ciherang. As the most potential bacteria, isolate $B$. subtilis subsp. subtilis STGG 14 is proved to have capability to produce 2 antifungal compounds, i.e psoralen, and xanthotoxin which belong to furanocoumarins group. This result reveals that antibiosis mechanism of isolate $B$. subtilis subsp. subtilis STGG 14 contributes to the reduction of blast disease severity in rice plants.

\section{ACKNOWLEDGEMENTS}

We would like to thank the Ministry of Research, Technology and Higher Education of the Republic of Indonesia for funding this research through Master of Education Program Leading to Doctoral Degree for Excellent Graduate (Pendidikan Magister menuju Doktor untuk Sarjana Unggul/PMDSU) 2018 and Penelitian Dasar-Unggulan Perguruan Tinggi (PD-UPT) to ATW. 


\section{REFERENCES}

Al-Barwani FM, El-Tayeb EA. 2004. Xanthotoxin and other furanocoumarins as phytoalexins in Pastinaca sativa L. roots. Sultan Qaboos Univ J Sci 9: 7-14.

Ali N, Sorkhoh N, Salamah S, Eliyas M, Radwan S. 2012. The potential of epiphytic hydrocarbon-utilizing bacteria on legume leaves for attenuation of atmospheric hydrocarbon pollutants. J Environ Manag 93: 113-120.

Asif M. 2015. Pharmacology potentials of different substituted coumarin derivatives. Chem Intl 1: 1-11.

Aslam K, Khosa MK, Jahan N, Nosheen S. 2010. Synthesis and applications of coumarin. Pak J Pharm Sci 23: 449-454.

Batool F, Rehman Y, Hasnain S. 2016. Phylloplane associated plantbacteria of commercially superior wheat varieties exhibit superior plant growth-promoting abilities. Front Life Sci 9 (4): 313-322.

Chaudhary D, Kumar R, Sihag K, Rashmu, Kumari A. 2017. Phyllospheric microflora and its impact on plant growth. Agric Rev 38: 51-59.

Costa TM, Tavares LBB, de Oliveira D. 2016. Fungi as a source of natural coumarins production. Appl Microbiol Biotechnol 100: 6571-6584.

Dean R, Van Kan JAL, Pretorius ZA, Hammond-Kosack KE, Di Pietro A, Spanu PD, Rudd JJ, Dickman M, Kahmann R, Ellis J, Foster GD 2012. The top 10 fungal pathogens in molecular plant pathology. Mol Plant Pathol 13: 414-430.

Dimkić I, Stanković S, Niśavić M, Petković M, Ristivojević P, Fira D, Berić T. 2017. The profile and antimicrobial activity of Bacillus lipopeptides extracts of five potential biocontrol strains. Front Microbiol 8: 1-12.

Gond SK, Bergen MS, Torres MS, Jr White JF. 2015. Endophytic Bacillus spp.: produce antifungal lipopeptides and induce host defense gene expression in maize. Microbiol Res 172: 79-87.

Hanene R, Abdeljabbar H, Marc R, Abdellatif B, Ferid L, Najla S. 2012 Biological control of Fusarium foot rot of wheat using fengycinproducing Bacillus subtilis isolated from salty soil. Afr J Biotechnol 11 (34): 8464-8475.

Harsonowati W, Astuti RI, Wahyudi AT. 2017. Leaf blast disease reduction by rice-phyllosphere actinomycetes producing bioactive compounds. J Gen Plant Pathol 83: 98-108.

Islam MR, Jeong YT, Lee YS, Song CH. 2012. Isolation and identification of antifungal compounds from Bacillus subtilis C9 inhibiting the growth of plant pathogenic fungi. Mycobiology 40: 5966.

Junaid MJ, Dar NA, Bhat TA, Bhat AH, Bhat MA. 2013. Commercial biocontrol agents and their mechanism of action in the management of plant pathogens. Intl J Mod Plant Anim Sci 1: 39-57.

Liao JH, Chen PY, Yang YL, Kan SC, Hsieh FC, Liu YC. 2016. Clarification of the antagonistic effect of the lipopeptides produced by Bacillus amyloliquefaciens BPD1 against Pyricularia oryzae via in situ MALDI-TOF IMS analysis. Molecules 21 (1670): 1-11.

Luo C, Zhou H, Zou J, Wang X, Zhang R, Xiang Y, Chen Z. 2015 Bacillomycin $\mathrm{L}$ and surfactin contribute synergistically to the phenotypic features of Bacillus subtilis 916 and the biocontrol of rice sheath blight induced by Rhizoctonia solani. Appl Microbiol Biotechnol 99 (4): 1897-1910.
Rastogi G, Coaker GL, Leveau JHJ. 2013. New insights into the structure and function of phyllosphere microbiota through high-throughput molecular approaches. FEMS Microbiol Lett 348 (1) : 1-10.

Ribot C, Hirsch J, Balzergue S, Tharreau D, Notteghem JL, Lebrun MH, Morel JB. 2008. Susceptibility of rice to the blast fungus, Magnaporthe grisea. J Plant Physiol 165: 114-124.

Semangun H. 2006. Pengantar Ilmu Penyakit Tumbuhan. Sleman, Yogyakarta, Indonesia. Gajah Mada University Press, Yogyakarta. [Indonesian]

Sha Y, Wang Q, Li Y. 2016. Suppression of Magnaporthe oryzae and interaction between Bacillus subtilis and rice plants in the control of rice blast. SpringerPlus 5: 1-13.

Sunera, Amna, Saqib S, Uddin S, Zaman W, Ullah F, Ayaz A, Ashgar M, Rehman S, Munis MFH, Chudary HF. 2020. Characterization and phytostimulatory activity of bacteria isolated from tomato (Lycopersicon esculentum L.) rhizosphere. Microb Pathog 140: 103966.

Suriani NL, Suprapta DN, Sudana IM, Temaja IGRM. 2015. Antifungal activity of Piper caninum against Pyricularia oryzae Cav. the cause of rice blast disease on rice. J Biol Agric Health 5 (8): $72-78$.

Tamehiro N, Okamoto-Hosoya Y, Okomoto S, Ubukata M, Hamada M, Nagawana H, Ochi K. 2002. Bacilysocin, a novel phospholipid antibiotics produced by Bacillus subtilis 168. Antimic Agents Chemother 46 (2): 315-320.

Tserkovniak LS, Roi AO, Kurdysh IK. 2009. Synthesis of amino acids of Bacillus subtilis IMV V-7023 in the medium with glycerophosphates. Microbiol Zhurnal 71: 18-23.

Wiraswati SM, Rusmana I, Nawangsih AA, Wahyudi AT. 2019. Antifungal activities of bacteria producing bioactive compounds isolated from rice phyllosphere against Pyricularia oryzae. J Plant Protect Res 59: 86-94.

Yadav RK, Karamanoli K, Vokou, D. 2010. Estimating bacterial population on the phyllosphere by serial dilution plating and leaf imprint methods. Ecol Soc 17: 47-52.

Yang L, Li S, Qin X, Jiang G, Chen J, Li B, Yao X, Liang P, Zhang Y, Ding W. 2017. Exposure to umbelliferone reduces Ralstonia solanacearum biofilm formation, transcription of type III secretion system regulators and effectors and virulence on tobacco. Front Microbiol 8: 1234.

Yang X, Ma X, Yang L, Yu D, Ni H. 2007. A novel bioassay method: determining bioactivity of compounds against rice blast (Magnaporthe grisea) with barley plants. J Plant Dis Protect 114: 228-231.

Yao X, Wu D, Dong N, Ouyang P, Pu J, Hu Q, Wang J, Lu W, Huang J. 2016. Moracin C, a phenolic compound isolated from Artocarpus heterophyllus, suppresses lipopolysaccharide-activated inflammatory responses in murine raw 264.7 macrophages. Intl J Mol Sci 17: 1-15.

Yu X, Wen Y, Liang CG, Liu J, Ding YB, Zhang WH. 2017. Design, synthesis and antifungal activity of psoralen derivatives. Molecules 22: 1-11.

Zhang S, Wang Y, Meng L, Li J, Zhao X, Cao X, Chen X, Wang A, Li J. 2012. Isolation and characterization of antifungal lipopeptides produced by endophytic Bacillus amyloliquefaciens TF28. Afr J Microbiol Res 6: 1747-1755.

Zhao GQ, Xinlan M, Xu Y. 2016. Isolation and identification of antifungal compounds produced by Bacillus Y-IVI for suppressing fusarium wilt of muskmelon. Plant Protect Sci 52 (3): 167-175. 